\title{
ARCHAEOLOGY
}

DOI: https://doi.org/10.32653/CH173638-657

Hizri A. Amirkhanov,

Dr. Sci., Prof., Acad. of RAS

Institute of Archeology of RAS, Moscow, Russia

amirkhanov@rambler.ru

\section{FORMATION, TAPHONOMY AND DATING OF THE NEOLITHIC LAYER OF THE CHOKH SETTLEMENT: DATA REVISION}

\begin{abstract}
To date, sixty years have passed since the excavations of V. G. Kotovich at the Chokh settlement and almost forty years after the field work was carried out there by the author. Over these decades, much has changed in the approaches to excavations and to the interpretation of materials obtained from layers with heterogeneous archaeological stratigraphy and complex lithological structure. A new understanding of the Chokh materials leads to the need to revise some of our ideas about the formation, taphonomy and relative chronology of finds and objects of the Neolithic layer of this site. With regard to the Chokh settlement, such an analysis leads to the need to consider the layer $\mathrm{C}$ (Neolithic) as a multi-component cultural and geological formation consisting of three or four consecutive microstratigraphic divisions. Based on this, an attempt is made in this paper to correct the ideas concerning the composition of archaeological material belonging specifically to the Neolithic layer. Special attention is paid to the highlighting of the homogeneous part that is related with the "floor" of the cultural layer C, or, in other words, the lowest, initial horizon (layer C, "bottom" or layer C, horizon 3), of which the formation of the Neolithic layer began. The breakdown of the cultural layer $\mathrm{C}$ into different living surfaces is carried out by linking the latter to the levels of occurrence of hearths and fire pits. This makes it possible, in particular, to isolate a homogeneous part of the material that is associated with the "floor" of the layer under consideration (layer C, "bottom" or layer $\mathrm{C}$, horizon 3). In this paper, we have tried to isolate from the totality of the archaeological material of Layer $\mathrm{C}$, its various parts, which can be attributed to the Neolithic layer with varying degrees of confidence.
\end{abstract}

Keywords: Chokh settlement; cultural layer C; microstratigraphy; taphonomy.

(C) H.A. Amirkhanov, 2021

(C) Daghestan Federal Research Centre of RAS, 2021 


\section{АРХЕОЛОГИЯ}

DOI: https://doi.org/10.32653/CH173638-657

Амирханов Хизри Амирханович, д.и.н., профессор, академик РАН Институт археологии РАН, Москва, Россия amirkhanov@rambler.ru

\section{ФОРМИРОВАНИЕ, ТАФОНОМИЯ И ПРОБЛЕМА ДАТИРОВКИ НЕОЛИТИЧЕСКОГО СЛОЯ ЧОХСКОГО ПОСЕЛЕНИЯ: ВЗГЛЯД ПОЛВЕКА СПУСТЯ}

Аннотация. К настоящему времени прошло шестьдесят лет после раскопок В.Г. Котовича на Чохском поселении и почти сорок лет после того, как там проводились полевые работы автором. За эти десятилетия изменилось многое и в подходах к раскопкам, и в интерпретации материалов, получаемых из слоев со сложной археологической стратиграфией и комплексной литологической структурой. Новое осмысление чохских материалов приводит к необходимости пересмотра некоторых наших представлений о формировании, тафономии и относительной хронологии находок и объектов внутри неолитического слоя этого памятника. Применительно к Чохскому поселению такой анализ приводит к необходимости рассмотрения слоя $\mathrm{C}$ (неолит) в качестве многосоставного культурно-геологического образования, состоящего из трех-четырех последовательных микростратиграфических подразделений. Исходя из этого, в данной работе предпринята попытка коррекции представлений, касающихся состава археологического материала, относящегося именно к неолитическому слою. Особое внимание уделяется вычленению той гомогенной их части, которая связана с «полом» культурного слоя $\mathrm{C}$, или, говоря иначе, самым нижним, начальным горизонтом (слой $\mathrm{C}$, «низ» или слой $\mathrm{C}$, гор. 3 ), с уровня которого началось формирование неолитического слоя. Разбивка культурного слоя С на различные поверхности обитания осуществляется с привязкой последних к уровням залегания очагов и кострищ. Это дает, в частности, возможность выделения гомогенной части материала, которая связана с «полом» рассматриваемого слоя (слой С, «низ» или слой С, гор. 3).

Ключевые слова: Чохское поселение; культурный слой С; микростратиграфия; тафономия.

(C) Амирханов Х.А., 2021

(c) Дагестанский федеральный исследовательский центр РАН, 2021 


\section{Introduction}

Over the past four decades, no long-term and comprehensive studies have been carried out on the Neolithic of the eastern part of the North Caucasus. During these decades, not a single paper has been published regarding the Neolithic of the said region. There have also been no attempts to re-examine the materials of the Chokh settlement (Layer C) in Central Dagestan [1]. Meanwhile, it is long overdue to return to the analysis of various aspects of the study of the site in the context of scientific realities formed more than sixty years after the first excavations by V.G. Kotovich [2] and a break that lasted more than forty years since the excavations were conducted there by the author.

The aim of the study is limited to the genesis and taphonomy of cultural deposits of Layer $\mathrm{C}$ of Chokh. For the time being, other aspects of the problem raised here are not addressed. The main question is the chronology of Layer $\mathrm{C}$, which is as important as identifying the dates of the underlying Mesolithic layers. The work on determining the age of cultural layers is currently underway and there is hope for its early completion.

Returning to the subject of the present study, we note that the analysis of the problem we are interested in, unfortunately, cannot be carried out with the necessary degree of detail on the materials of previous excavations. Some of the current issues simply could not be in the focus of our attention during the research conducted several decades ago. This applies, in particular, to the use of microstratigraphic analysis. Such a concept in Soviet, and perhaps not only in Soviet archaeology, was very rare. As for the research of the Chokh settlement, at that time the author had to argue in numerous scientific disputes, proving the need for the dating of the Neolithic layers, accepted by all experts without exception as relating to the Mesolithic Age. This task determined the main focus of our study.

Currently, the study of the Neolithic materials of the site should be focused on solving other issues. The crucial ones are the problems of dating and microstratigraphy of cultural deposits. It is important to find the answers on how homogeneous is the Chokh layer, how long it formed, which of the categories of finds and objects belong to the initial stage of the formation of this stratigraphic unit? A separate and very important issue is the cultural continuity between the Mesolithic and Neolithic materials in the Chokh stratigraphic column.

\section{General information about the site and the Neolithic layer C: geographical position, geomorphological position, history of research, general planigraphy, and stratigraphy}

The Chokh settlement is situated on the Kegersky (Turchidag) plateau in the central part of the Inner (Mountainous) Dagestan [1]. From the northwest to the southeast, the plateau stretches for $20 \mathrm{~km}$, from the southwest to the northeast - for 10 
$\mathrm{km}$. Its maximum height at the top of Mount Turchidag reaches $2400 \mathrm{~m}$; the minimum altitude is approximately $1600 \mathrm{~m}$. Hypsometrically, the plateau is divided into three parts of various heights. The lowest part is located on the right bank of the Kara-Koisu River in the alignment of the village of Gunib. It has a height of 1600-1700 $\mathrm{m}$ and is the smallest area compared to others. The middle part of the plateau (Fig. 1), in which the Chokh settlement is located, covers the basin of the upper reaches of the Bakdakuli River (the right tributary of the Kara-Koisu river), has a height range of $1750-2240 \mathrm{~m}$, and occupies the largest area. The latter represents exactly that part of the area that can be called the "economic territory" of the Neolithic residents of the Chokh settlement. The site itself is situated at the bend at the base of the right limestone side of the Bakdakuli river gorge (Fig. 2). The exposition is south-western; the place is well protected from the winds (Fig. 3).

The site was discovered by V.G. Kotovich - a member of the Mining Archaeological expedition (the head of the expedition - R.M. Munchaev) of the Institute of History, Language and Literature of the Dagestan branch of the USSR Academy of Sciences in $1954^{1}$. It was the first multi-layered Stone Age site in the North Caucasus with cultural remains preserved in the original occurrence.

The history of systematic excavations of this settlement can be divided into three stages (Fig. 4). The first stage lasted from 1955 to 1957 and was associated with the works of V.G. Kotovich. The beginning of the second stage can be attributed to 1974, when the author of the present paper, a graduate student of the Leningrad Department of the Institute of Archaeology of the USSR Academy of Sciences, carried out his first excavations there as part of his dissertation thesis. The continuation of these works on a larger scale was conducted in 1980-1982. Then there was a long break, and 2021 marked the beginning of the third stage of excavations, which promises to provide additional information and a new understanding of many aspects related to the settlement and relevant to the issues of the Neolithic Age of the entire North-Eastern Caucasus.

At the initial stage of the excavations, it was already possible to consider the presence of post-positional changes, at least in the upper part of cultural deposits. These were, first of all, disturbances related to excavations (in particular, the extraction of flint as raw materials for tools) carried out by humans for a long time (including the $20^{\text {th }}$ century) after the completion of the formation of the layer. The second type of disturbance was associated with the activity of burrowing animals. These points are actually not specific to the deposits of the Chokh settlement alone, and are characteristic of almost all sites containing several cultural layers or horizons. When studying the Neolithic sites of this kind, this aspect is not always given the necessary attention.

After the completion of the excavations in 1957, V.G. Kotovich identified two Mesolithic and four Upper Paleolithic cultural layers on the site (Fig. 5). The lower, sixth archaeological layer was discovered only in 1957 and was opened by a prospecting

1 Munchaev R.M. Report of the Dagestan archaeological expedition of 1954. Archive of the IA of the USSR Academy of Sciences. R-1. File 1136. 
trench on an area of 1 sq. $m$. If the separation of the latter was not disputed by anyone, the division of the overlying deposits subsequently caused objections from A.A. Formozov' . In an article devoted to the review of studies of Mesolithic sites of the Caucasus, he advocated for the distinguishing of two cultural horizons in the Chokh settlement. According to A.A. Formozov, Layers 5-1 should have been considered a single layer and, based on the presence of trapezoids in it, dated it to the Mesolithic Age. As for the lower layer (Layer 6 according to V.G. Kotovich), he considered it possible to attribute it earlier than the Mesolithic Age, namely, to the Upper Paleolithic Age [3].

N.O. Bader used the materials of the Chokh settlement in connection with the solution of the issue of the cultural variants of the Upper Paleolithic and Mesolithic Ages of the Caucasus $[4 ; 5]$. Regarding the dating of the site's assemblage, he limited himself to pointing out the unresolved issue, but did not express any doubts that the Upper Paleolithic and Mesolithic layers were represented there. The same opinion was held by almost all researchers who dealt, in one way or another, with the issue under consideration.

After new excavations were carried out by the author of the paper in 1980-1982, the archaeological stratigraphy of the site was significantly reconsidered (Fig. 6). The new scale now included three layers - two Mesolithic (Layers D, E) and one Neolithic (layer C). In addition, a relatively thin horizon of the Bronze Age ( $\mathrm{C} 1$ ) was identified, that occurred directly above the Neolithic layer without a sterile stratum. The floor of this horizon was broken off by the level at which the remains of a stone structure (most likely a wall), which were identified in the eastern part of the excavation, occurred above the sediments of Layer $\mathrm{C}$. In the rest of the area, there were no clear indicators by which it would be possible to distinguish this horizon of cultural deposits with any confidence. This, of course, does not mean that the Bronze Age finds could not be applied to this part of the excavation. Indisputable products in the form of bifacially processed inserts of a sickle and an arrowhead - forms well known for the time of the Middle Bronze and later, - were found, for example, in squares $\mathrm{r}-8$, n-6, k-9. These artifacts were deposited both in the upper and in the second and third conventional excavation horizons of Layer $\mathrm{C}$.

It is noteworthy that there are no whole samples among them, only blanks or fragments. With a high degree of probability, we can attribute these remains to a workshop. This means that in the Bronze Age, people used this station as a workshop for the manufacture of tools at the site of the extraction of flint raw material from the Neolithic cultural Layer C. And since Layer C had already been covered by this time, the extraction of flint raw material could not be carried out without certain digs and disturbances into the Neolithic layer, where only flint was contained. Hence the ingress of single "defective" flint artifacts into different horizons of the layer disturbed by the excavation.

2 Munchaev R.M. Report of the Dagestan archaeological expedition of 1954. Archive of the IA of the USSR Academy of Sciences. R-1. File 1136. 
Thus, the new excavations provided us with a different breakdown of the geological and archaeological sequence of layers. These data have already been described in detail and published [1]. Layer $\mathrm{C}$ is described as a "dark gray light loam saturated with small and medium-sized crushed stones with the inclusion of individual fragments of limestone. The occurrence is mainly horizontal. Contacts: lower - clear; upper - distinguishable. Rich in cultural remains (building remnants, flint, ceramics, etc.). The color of the layer is given by ash and cinder" [1, p. 23-24].

On the area of 110 sq. $m$ of excavation No. 2, investigated by the author, the Neolithic layer occurred at a depth of, on average, $40 \mathrm{~cm}$ from the modern surface. The thickness of the layer in its lithological expression ranged from 45 to $60 \mathrm{~cm}$ (on most of the layer $-45 \mathrm{~cm}$ ). Visible signs of postpositional changes in the layer have not been detected, except for numerous small rodent burrows. The floor of the cultural layer was clearly broken off by the deepened Hearth 1, located on squares L-M-6, approximately in the center of the remains of a stone semicircular structure, as well as by a sharp change in color from dark gray (Layer C) to yellowish-brown (Layer D).

\section{General archaeological characteristics of the Neolithic layer C}

The main features of the layer compared to the underlying Mesolithic layers on the excavated area of the site are as follows: the significantly greater richness of archaeological material; the dark gray color of sediments associated with the abundant inclusion of ash and cinder; the presence of hearths, fireplaces, and architectural remains; the content of ceramic fragments, a variety of qualitative composition of finds reflecting the production and household activities of the inhabitants of the settlement - an indication that the inventory belongs to the population familiar with agriculture and cattle breeding. The presence of reaping tools, grain grinders, and bones of domestic animals in the finds is especially indicative.

The layer under consideration lies directly on the Mesolithic Layer D; however, this hardly indicates a cultural-stratigraphic continuity between the Mesolithic and the Neolithic deposits of the site. Layer $\mathrm{C}$ has a horizontal position on the entire excavated site, whereas the underlying Mesolithic layers are located with a noticeable slope in the opposite direction from the rock massif. At the same time, the slope is steeper the more the layer moves away from the rock. These differences like the occurrence of layers may indicate the presence of a break in sedimentation between the Neolithic and the underlying Mesolithic layers. The observed pattern also allows for the possibility of some leveling of the habitat surface at the time of its settlement by the Neolithic population. Nonetheless, by the beginning of the formation of Layer C, the surface of the underlying cultural Layer D was "exposed" by erosion processes, and perhaps partly by human disturbance aimed at planning inhabited areas.

Based on the above, it is impossible to exclude the possibility of at least minimal mixing of the archaeological material from the layers under consideration. If that was the case, then exactly to the extent that it is characteristic of any other site of the 
Stone Age, where one cultural layer overlaps another without a sterile layer between them. In such cases, it can never be guaranteed that the inhabitants of the upper of the two levels did not extract flint artifacts from the layer on which they settled and did not use them again. Such cases can often be clearly identified. It should be noted that researchers do not pay the necessary attention to this aspect, considering collections formed from the cultural layers as "pure assemblage". However, it cannot be denied that in most cases, perturbations of this type do not change the general characteristics of the cultural remains of the studied layers.

The archaeological remains of Layer $\mathrm{C}$, consisting of various categories of stone products, bone tools, architectural elements, floral and faunal remains, have distinct features. They are evident, for example, in flint equipment. The latter contains notable features of evolution that reflect the chronological position of the layer and the economic functions of stone tools, which underwent a radical change at the Neolithic stage of their development.

\section{"Internal stratigraphy" (microstratigraphy) of Layer C}

As it was accepted many decades ago in the methodology of Paleolithic research, the geological and stratigraphic principle was established as the basis for dividing the cultural deposits of Chokh (as mentioned before, at that time, the site was attributed to the Upper Paleolithic and Mesolithic Ages). It was only at the advanced stage of the excavation that it became clear that the lithological thickness of the layer consists of more than one discrete horizon of cultural deposits. Consideration of the latter as a single stratigraphic unit, although it formed for quite a long time, was technically correct. Moreover, as mentioned previously, the main purpose of the stratigraphic study of the site at that stage of research was to find out what at least the general stadial belonging of the site's layers was.

According to modern requirements of the methodology, the excavations should have been carried out not with conventional horizons, as was done then, but using a microstratigraphic approach to stripping the layer, assuming the fixation of real multi-temporal habitat surfaces that can be formed during the formation of even a single lithological layer. The "absolute purity" of the collections of individual discrete horizons would hardly have been achieved even with this method of excavation - the layer experienced too obvious impacts of post-positional destructive factors in the form of bioturbations and destructions associated with human activity. Nevertheless, we regret that in those years the microstratigraphic method of layer stripping was not widespread.

Are there any data now, many years later, that make it possible to perform at least a general microstratigraphic division of the Neolithic layer $\mathrm{C}$ of Chokh? These data can be found in the documentation of the excavations of 1981-1982. In the descriptions of the studies and graphic plans related to that time, the location of hearths and fire pits along the vertical of this layer was recorded. In total, two hearths and three 
fire pits were identified in the lithological Layer C, recording four different altitude levels with their location in this cultural layer (Fig. 7). Below is a description of these objects.

Hearth 1 partially occupies squares л-м - $6(1-\mathrm{m}-6)$. The hearth is sunk from the floor of the cultural Layer C into the underlying Mesolithic cultural Layer D to a depth of $8-10 \mathrm{~cm}$. Has a round shape in plan, $40 \mathrm{~cm}$ in diameter. At the southern and northern edges of the hearth, one stone with a diameter of 28 and $25 \mathrm{~cm}$ is placed horizontally against each other. In height, the stones have almost the same dimensions - 13 and $11 \mathrm{~cm}$. The location of the stones, their selection, and relative isolation leave no doubt that they served as a hearth stand. The walls of the hearth are vertical, heavily charred; the bottom is flat and also charred. The hearth pit contains an ash-carbonaceous filling. The fuel was broad-leaved timber: oak, maple, hornbeam, etc. (despite the fact that the absolute height of the location of the cultural layer is $1725 \mathrm{~m}$ ). The washing of the filling of the hearth delivered a very important material in the form of burnt grains of cultivated cereals.

Hearth 2 occupies the north-eastern corner of the square $ж-3-6$; zh-z - 6 and the north-western corner of the square $3-6 ; z-6$. Has a round shape, with a diameter of about $50 \mathrm{~cm}$. On the western side, it is bounded by a huge limestone block standing vertically, in the rest of the circumference there are nine small stones. The filling of the hearth contains a great quantity of charcoal and ash. The areas of the layer adjacent to the hearth are richer with material than others, especially in ceramics. Archaeological finds with heavily charred surfaces were also uncovered in the very filling of the hearth. The level of the described hearth is $10 \mathrm{~cm}$ higher than the floor of the dwelling and, consequently, the level of the main hearth.

Fireplace 1 is located in the square $3-7 ; \mathrm{z}-7$ and partially covers the square $3-8 ; \mathrm{z}-8$ of the excavation site. The outlines are oval. The dimensions on the long axis are 65 $\mathrm{cm}$, on the short axis $-55 \mathrm{~cm}$. The contents of the fire pit are an ash-carbonaceous mass with the inclusion of archaeological remains, some of which are heavily burnt. The thickness of the ash spot is $3 \mathrm{~cm}$. Next to it, there is a more intense accumulation of archaeological material than the average for the excavation as a whole. Fire pit 1 is located $38 \mathrm{~cm}$ above the floor of the dwelling.

Fireplace 2 is situated in the $\mathrm{\kappa}-8$; k-8 square. It has rounded outlines; the diameter is $54 \mathrm{~cm}$. The filling is dark-colored, ash-carbonaceous. It contains heavily burnt animal bones, flint, as well as ceramics. The base of the fire pit is also burnt. The thickness of the ash spot is $4 \mathrm{~cm}$. The space surrounding the fire pit is richer in material (especially ceramics) than the distant sections. The level of the described hearth is 5 $\mathrm{cm}$ higher than the floor of the dwelling and the main hearth.

Fireplace 3 is located in the $\phi-9$; $\mathrm{f}-9$ square. It has rounded outlines; the diameter is $30 \mathrm{~cm}$. The height above the floor level is $5-6 \mathrm{~cm}$. According to other key indicators, this object is close to the fire pits described above.

Thus, within the cultural deposits in the eastern part of the site, we have four levels of Layer C, which are marked by two hearths and three fire pits located at different 
levels. Of these, only Hearth 1 is stratigraphically and planigraphically connected with the bottom of the cultural Layer $\mathrm{C}$ and the floor of the living space itself. In typological terms, as well as in diversity, richness, and composition of the archaeological material concentrated around it, this hearth differs from other analogous objects of this layer.

At the level of 5-6 cm above the main hearth, two fire pits (2 and 3) were identified, located at a considerable distance from each other. They functioned at the time when the cultural layer accumulated to the specified 5-6 cm. Chronologically, they formed later than Hearth 1, but relative to each other, they are probably more or less concurrent. Then up the layer goes Hearth 2, located $10 \mathrm{~cm}$ above the floor level, and finally, Fire pit 1, identified $38 \mathrm{~cm}$ above the floor.

\section{In situ materials and the "intrusive" part of the finds of Layer C}

The interstratification of the above-mentioned hearths and fire pits can be seen as a sufficient reason to consider Layer $\mathrm{C}$ as a combination of four different cultural horizons. A variant of this interpretation of the layer was assumed by the author earlier when generalizing the publication of the materials of the site [1]. The necessary attention was also paid to the issue of homogeneity of the archaeological materials of Layer $\mathrm{C}$ when looking at it from the point of fractional stratigraphic division. One thing could be determined without question - the cultural-chronological and stadial homogeneity of flint industry of Layer C. It was difficult to consider ceramics due to the fragmentation of its remains in the layer and the scarcity of general data on the nature of this category of equipment at the stages of the Neolithic-Eneolithic-Early Bronze Ages in relation to the Northeast Caucasian sites. As for the faunal remains presented here in a multitude of finely fragmented pieces, the possibility of their "migration" into the vertical layer, as well as on other similar sites, cannot be ruled out. This follows from the peculiarities of the formation of the layer under consideration and its taphonomic characteristics.

With the modern archaeological vertical breakdown of deposits of Chokh (according to Dig 2), it is necessary to single out a special archaeological horizon called "Layer C bottom" or "Layer C Horizon 1" that part of the Neolithic layer that corresponds to the floor of the cultural layer. The objects and finds belonging to this level ("Layer C bottom") of the cultural layer are as follows:

1) Hearth 1 ;

2) cultural deposits up to a height of 5-6 cm above the floor level of the cultural Layer C;

3) likely the remains of a stone wall on the section of squares $\mathrm{z}-\mathrm{f}$.

4) almost the entire flint equipment;

5) at least part of the ceramics, which is characterized by the shape of pots and bowls, a relatively thin wall, high density, the use of local sanded clay and additives in the form of fine landwaste and grog, smoothing of the surfaces of vessels in some cases to a soft glaze; 
6) the main part of bone equipment;

7) at least part of ground stones (grain grinders), and grinding pestles;

8) part of finely fragmented animal bones;

9) timber collected for filling Hearth 1: oak, maple, hornbeam, etc.;

10) paleobotanical remains of cereals obtained from washing the carbonaceous filling of Hearth 1 and directly above it. The latter include the following cereals: emmer wheat (T. dicoccum Schrank), hulled barley (N. vulgare L. polystichum), hullless barley (H. vulgare var. nudum) and weeds of crops of cereals and flax: brome grass (Bromus sp.), corncockle (Agrostema sp.), sedges (Cyperacea).

The following objects and finds correlate with the following (second from bottom to top) archaeological horizon of Layer C;

1) Hearth 2;

2) presumably, a rebuilt section of the fence wall on the squares g-zh. The horizon associated with Hearth 2 accumulated after the reconstruction of the stone structure on the g-zh squares. The fragment of the stone structure itself differs significantly from the rest of the wall and allows to assume a later reconstruction of the original stone structure in accordance with other purposes. The basis for this assumption is, in particular, that on the described segment, a single-row masonry of medium-sized stones stands out structurally from the rest of the (Neolithic) part of the wall;

3) a part (possibly considerable) of finely fragmented animal bones;

4) individual bone items (possibly);

5) individual ground stones (possibly);

6) individual fragments of ceramics (possibly);

7) individual flint items (possibly);

The horizons marked by the fire pits, lying above Hearth 2 are lithologically and archaeologically homogeneous, with no signs of trampled spots. Everything suggests that even after the completion of the second stage of the "life" of Layer C, people visited this place from time to time and left traces of their stay. It lasted as long as people with a culture identical to the one we recorded in the layer from the Chokh settlement lived on the territory of this region. Thus, the considered microstratigraphic levels of this archaeological layer reflect the dynamics of the life of a settlement with a homogeneous and stable culture over a period of time, the duration of which remains unclear, but in a stadial respect fits into the Neolithic period.

We exclude the issue of interpretation of construction remains associated with Layer $\mathrm{C}$ in this paper, which is directly related to the problem of dwellings and settlements in the Neolithic period of the site's functioning. It requires a separate and detailed study. There are serious grounds for offering explanations other than before of the essence of the stone structures of Layer $\mathrm{C}$ and the approach itself to the problem of house identification in the Chokh settlement. As for the stratigraphic view within Layer $\mathrm{C}$ of the stone structure in the form of a wall, the above indicates the different correlation of two different parts of it. 


\section{Layer C1}

During the excavations of the site, thin Horizon $\mathrm{C} 1$, dating back to the Bronze Age, was identified. In the excavations of V.G. Kotovich in previous years, such stratigraphic unit was missing. A newly isolated layer was not associated with a separate lithological unit. The finds of this layer belonged to the upper level of the lithological Layer C. The basis for distinguishing this level as a separate archaeological and stratigraphic unit served the remains of a stone wall identified in squares s-6-9 of excavation No. 2. The lower row of stones of this wall was located at the level of $+40-45 \mathrm{~cm}$ from the floor of the cultural Layer $\mathrm{C}$ and the stone structure associated with the Neolithic layer.

Judging by the preserved remains, the wall of the post-Neolithic cultural Horizon C1 was single-row, had a crude masonry of medium-sized stones without coating and mortar. This wall preserved in 1-2 tiers, despite the fact that on the same site a much more substantial wall of the Neolithic has up to 6 tiers of masonry.

Excavations on the area of this horizon did not yield any significant results. The few materials recovered cannot be considered as a closed assemblage. The reason for this is the impossibility of identifying at this level the archaeological signs of the floor, indicative of the entire area of the layer under consideration. The latter has to be determined by the level of the lower row of the wall stones, which is a fairly approximate indication.

The presence of the described Horizon $\mathrm{C} 1$ in itself is an indication of the possibility of infiltration of Bronze Age objects into the horizons of the Neolithic Layer C. In some cases, these foreign cultural inclusions are unmistakably recognized. These, for example, are bifacial products in the form of inserts of reaping tools at the stage of their manufacture or their fragments. Other flint products re-formed by later secondary processing belong to the same group of artifacts. The use of large flat bifacial retouching during their processing indicates the intention of the craftsman to re-shape the Neolithic scraper, for example, into a typical Bronze Age arrowhead. At the same time, the extraction of raw material in the form of flint was carried out by digging up the Neolithic layer lying directly under the feet of the craftsman - another factor of the intrusion of archaeological material from the upper horizons of the layer to the lower and back.

The small and quite rare fragments of ceramics found in this horizon do not allow us to restore the shapes of vessels. Fragments with a yellowish surface and a distinctive ornament in form of a "chopped" roller are characteristic of this horizon. Some of the fragments of ceramics are similar in appearance to the assemblage of this category of finds characteristic of the Neolithic layer.

A notable distinctive feature of faunal remains originating from the described horizon is the presence of horse and cow teeth.

The bifacial processed flint products and ceramics with an ornament in the form of a "chopped" roller can serve as specific archaeological indicators for dating Horizon 
C1. These artifacts indicate the Bronze Age, although bifacially processed arrowheads with a stem were published in previous works of some authors on the assemblages attributed to the Neolithic of the Caucasus [6, Table 9, etc.].

The presence of a Bronze Age burial ground about $1 \mathrm{~km}$ from the Chokh settlement is also important in determining the cultural and chronological framework of Horizon C1. In stone crypts of this burial ground, dating to the time of the Kayakent-Kharachoy culture ${ }^{3}$, in particular, re-formed scrapers for secondary use with flat retouching from the ventral surface and bifacially processed flint products were found [1, p. 32]. These items are made of a variety of flint, the natural outcrop of which are unknown on the Turchidag plateau. The only place of concentration of this material in the closest vicinity was the Chokh settlement, where at that (Mesolithic and Neolithic) time this raw material came from afar. Thus, the people who left the burial ground knew the location of the Chokh settlement, visited it and extracted flint from its cultural layers. Something similar took place not only here and not only in the ancient sites of the Caucasus, but also in modern times, in particular, during the Great Patriotic War, when the flint and firesteel were used by the local population.

The findings of Horizon $\mathrm{C} 1$ demonstrate that people in the Bronze Age not only visited the location of the Chokh settlement, but also made use of this site. This use, however, was episodic. The primitive structure has no signs of a dwelling and does not correspond to the nature of Dagestan's house-building in the Bronze Age in any way. We are most likely dealing with a pen or enclosure for temporary keeping of livestock. In the Bronze Age, transhumance was already practiced in Dagestan. There are also a large number of sites associated with seasonal grazing on summer alpine pastures. All these sites are, in fact, caves, grottos, overhangs, and just rock outcrops more or less adapted for the enclosure [7]. This appears to have been the same in the case described above.

\section{The issue of dating; duration of accumulation of cultural sediments of Layer $C$}

By the time of the author's publication of the site's material (the mid-8os of the last century), there had been no radiocarbon dating of the Chokh settlement. The possibility of dating, however, exists. There is charcoal material from the 1957 excavations, as well as animal bones. Bone artifacts can also be used for direct dating. It is also possible to attract carbon deposits from the walls of ceramic vessels. The task of obtaining radiocarbon dates for Layer $\mathrm{C}$ is now considered urgent and measures are being taken to solve it.

Data for determining the age of the layer are currently limited by the possibilities of the archaeological comparative-historical method itself and the results of the spore-pollen analysis of the complete stratigraphic sequence of the site.

3 Later, R.G. Magomedov attributed this site to the Ginchin culture of the Middle Bronze of Dagestan. 
According to the definitions made by MSU Prof. I.A. Karevskaya, spore-pollen spectra at the depth level of the Neolithic layer $\mathrm{C}$ in terms of the total ratio of pollen and spores are not similar to modern ones and differ greatly from the spectra characteristic of the underlying Mesolithic layers of the site. They differ from the ones below in the section by a high percentage of tree species (up to 15-16\%), represented mainly by pollen from various pines, birches, elm, as well as single grains of spruce, yew, oak, holly, acacia (see pollen diagram [1, p. 28]). In the group of herbaceous and shrubby vegetation, the pollen of cereals, sedges and steppe grasses plays a crucial role. Therefore, the horizons directly above the upper Mesolithic layer of the section of the site accumulated under conditions of climate mitigation; steppe and meadow plant communities displaced semi-desert xerophytic groups. The degree of afforestation of the territory exceeded the modern one, and the composition of the dendroflora was noticeably richer, which indicates more favorable climatic conditions.

The matching data obtained by two different methods - palynological and general paleobotanical onse - is also noteworthy. According to the definitions made by G.N. Lisitsyna on charcoal, the filling of Hearth 1 consisted of charred oak, ash, hornbeam, maple, and organically related shrub plants. If these tree species were used as fuel, then it is clear that during the functioning of Hearth 1 of the Neolithic period, they grew in the close vicinity of the settlement.

The floral composition characteristic of the underlying Mesolithic layers differs significantly from that represented in Layer C, while in the archaeologically sterile layers underlying the Mesolithic layers, it contrasts sharply.

In general, I.A. Karevskaya distinguishes three different phases of vegetation for this sequence. The first one (from top) has already been described in the paper. The second one combines Mesolithic Layers D, E, and the third one is associated with Layers F, G, which lack any archaeological remains. For the third (the earliest in the section) phase, conditions are reconstructed with almost complete absence of indications of forest vegetation, but the presence of species adapted to the conditions of deserts and semi-deserts, as well as distinguishing in frost and drought resistance. The existing set of taxa corresponds to the conditions of sharp xerophytization of the climate and the effects of glacial expansion in the mountains. Based on the general geological and geomorphological location of the site, paleogeographic characteristics of various levels of lithological sediments, the time of formation of the pre-Mesolithic Layers $\mathrm{F}$ and $\mathrm{G}$ of Chokh can be correlated with the stage of the Younger Dryas (circa 13-11 thousand years ago (on a calibrated scale)). This assumption is supported by the radiocarbon date (so far, the only one) for the Chokh Layer D [ $\operatorname{IGAN}_{\mathrm{AMS}} 6313$ : (1 sigma) cal BP 12830-12959; (2 sigma) cal BP 12784-13010].

In the sediments of the Mesolithic layers of the site, the dominance of cold-loving desert and semi-desert xerophytes, typical for underlying layers, is replaced by conditions with a predominance of mountain steppe with the presence of forest formations. The latter indicates climate softening and a decrease in aridity, which accord- 
ing to the general paleoclimatic scale of the early Holocene should correspond to the Preboreal period.

The spore-pollen diagram of the sediments of the Chokh settlement was compared with the generalized spore-pollen diagram of quaternary sediments of the Western Caspian Region [8, pp. 96-106]. It was revealed that according to the total composition of pollen and spores, the percentage of pollen grains of the dominant vegetation cover (Chenopodiceae, Ephedra, Artemisia, Gramineae) and the trend in their change, the three groups of spore-pollen spectra from Chokh are similar to the spectra of three phases in the development of flora of the Late Pleistocene-Holocene period of the Western Caspian Region. The first of these phases is synchronous with the end of the Late Khvalyn transgression. The second corresponds to the Post-Khvalyn regression, and the third phase is compared with the New Caspian transgression.

According to radiocarbon and thermoluminescent analyses, sediments of the Post-Khvalyn period in the Caspian Region accumulated 14-20 thousand years ago, at the end of the Late Pleistocene. Sediments of the second phase belong to the Mangyshlak regression. The beginning of the latter based on averaging radiocarbon dating belongs to the time of about 10 thousand years ago (on an uncalibrated scale), and the maximum in radiocarbon chronology falls on 9 thousand years ago [9].

The grounds given for dating the Neolithic materials of Chokh by the time of the beginning of the New Caspian transgression (no later than 8.5 thousand years ago on an uncalibrated scale), of course, require clarification using a series of radiocarbon dates. This work has now begun and its results may allow in the near future to determine a more accurate placement of the site in the chronology of the Neolithic of the Caucasus.

Let us examine the issue of the relative age of the Neolithic materials of Chokh. Based on the archaeological periodization of the Neolithic of the Caucasus, the desired chronological stage should be unambiguously defined as the stage preceding the presence in both the Northern and Southern Caucasus of such a highly distinctive category of products as trapezoids "with planed backs". In periodization terminology, this corresponds to the Late Neolithic period, and in absolute terms, to the time within the 6th millennium BC (in the system of calibrated chronology). These tools (trapezoids with planed backs) are common for the layers of those Neolithic sites of the Shomutepe-Shulaveri culture, the datings of which reach the middle of the 6th millennium BC and a little earlier. They are even more typical for the late Neolithic and Eneolithic periods of the Western Caucasus.

Regarding the issue under consideration, it is highly indicative that from the point of the regional (all-Caucasian) scheme of the evolution of stone tools, cultures with trapezoids with planed backs and the stone industry of Layer $\mathrm{C}$ of the Chokh settlement are completely different phenomena in stadial terms. Clearly, the North Caucasian cultural layer with trapezoids with planed backs is more recent in terms of the Neolithic industry of Chokh. 
One of the most significant characteristics of the stone industry of Layer C from the Chokh settlement is its undoubted genetic connection to the local Mesolithic culture, represented, in particular, on the site. The Neolithic industry here is a continuation of the local Mesolithic tradition. It does not reveal any technological or typological gap and retains typological characteristics specific to the Chokh culture during the transition from the Mesolithic to the Neolithic period.

Other manifestations are recorded when the Chokh Neolithic culture itself was replaced by a cultural stadial complex called Eneolite in the old tradition and is represented in Dagestan by the Ginchi settlement [10]. The latter is characterized by such indicators as the large-plate stone industry with primary splitting, possibly with the use of a lever device; decorated ceramics, obsidian exports from Transcaucasia, curved sickles with large inserts common for the Transcaucasian Late Neolithic Age (with the common context of the abundant and diverse bone equipment). All of these characteristics above typologically and fundamentally differ from the Neolithic Chokh culture. The Ginchi culture is an analog of the Transcaucasian Late Neolithic (in the modern sense) culture, most likely in its final stage. The upper chronological boundary of the sites of this culture, according to archaeological data, passes below the time of existence of the cultural phenomenon of the Caucasus called "Tsopi-Sioni" or sometimes "Tsopi-Sioni-Ginchi" culture. There are several sites in Dagestan whose evolutionary status and cultural content resemble the layer of sites of the specified type [7].

Regarding the absolute age of the Dagestan site of the Ginchi type, we once again face the complete absence of absolute dates. Currently, there is, perhaps, the only date obtained from coal in the remains of the workshop in the Holocene soil layer (Layer 1) of the Mukhkai 2 site: $6140+/-40$ (GIN-15865). In calibrated version (28), this date falls within the segment of 5256-4962 (BC; cal.), which corresponds to the upper boundary of the Late Neolithic framework of Transcaucasia [11]. This date confirms the fact that, in stadial, evolutionary terms, the Neolithic culture represented by the Chokh layer precedes the late sites of the Neolithic culture of Transcaucasia and its derivative on the territory of mountainous Dagestan - the Ginchi culture.

\section{Conchsion}

1. On the uncovered in 1980-1982 area of the Chokh settlement, finds deposited in situ and definitely belonged to the Neolithic period, which originated from the lower horizon of Layer C (Layer C "bottom") 5-6 cm in thickness. The bottom of the horizon corresponds to the floor of cultural Layer C, marked by Hearth 1 . The intrusion of artifacts from overlying horizons is possible, but not to a greater extent than on any other multilayer site of this type.

2. Revision of the formation of Layer $\mathrm{C}$ of Chokh does not change the conclusion that the said layer contains a complete set of features of the "Neolithic package", 
including both archaeological materials and socio-cultural characteristics arising from these data.

3. Our previous conclusions regarding the stadial status of materials from different layers of the site and the cultural continuity between the Mesolithic and Neolithic layers of Chokh remain unchanged.

4. The question of the absolute date of the site remains unresolved. Indirect data suggest both the aging of the Neolithic layer, and the preservation of the existing relative dating.

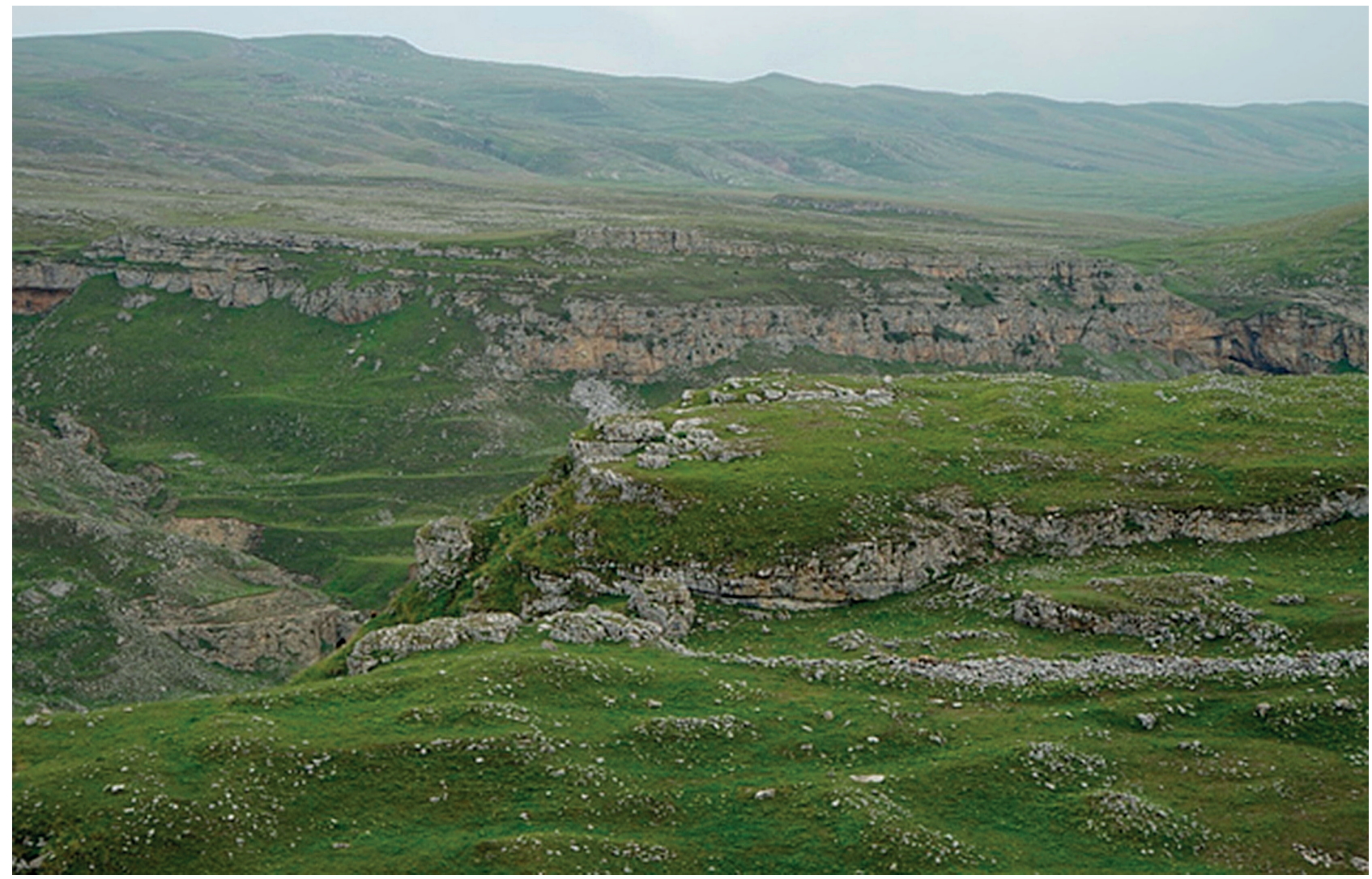

Fig. 1. General view of the middle part of the Keger plateau at the location of the Chokh settlement

Рис. 1. Общий вид средней части Кегерского плато в месте расположения Чохского поселения 


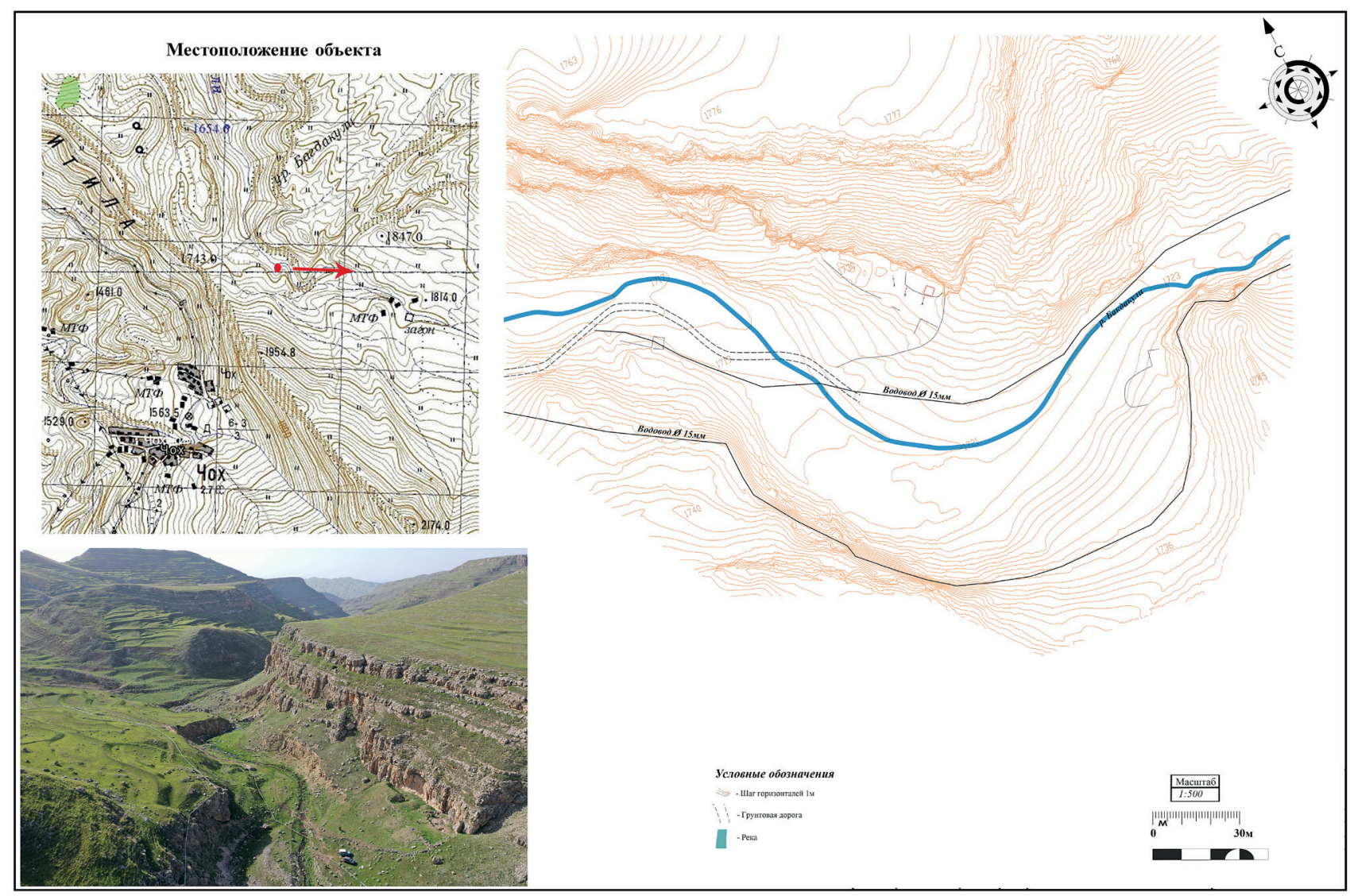

Fig. 2. Chokh settlement. Orthophotoplan with reference to the map

Рис. 2. Чохское поселение. Ортофотоплан с привязкой к карте

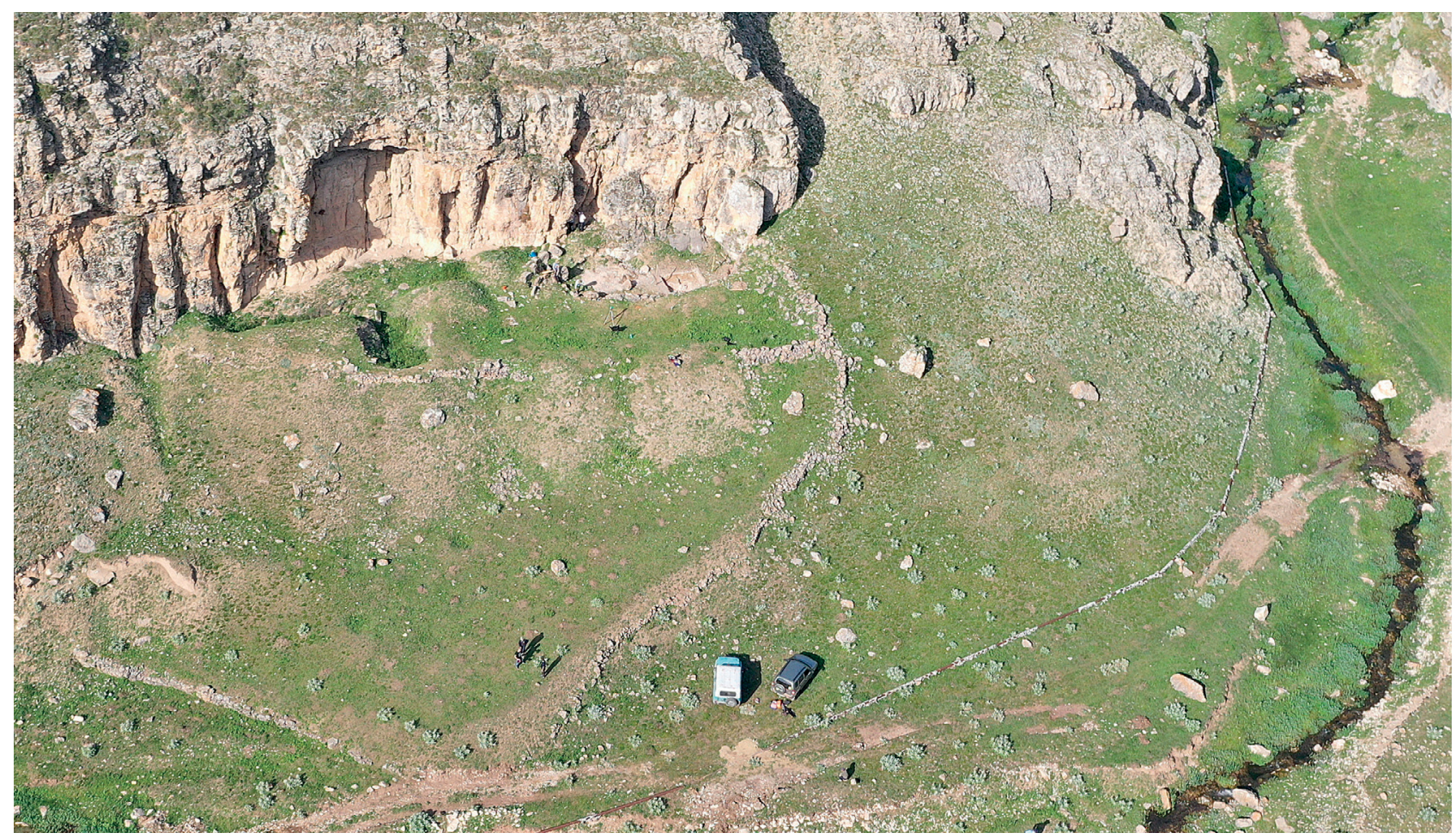

Fig. 3. Chokh settlement. General view from the S-E

Рис.3. Чохское поселение. Общий вид с Ю-В 


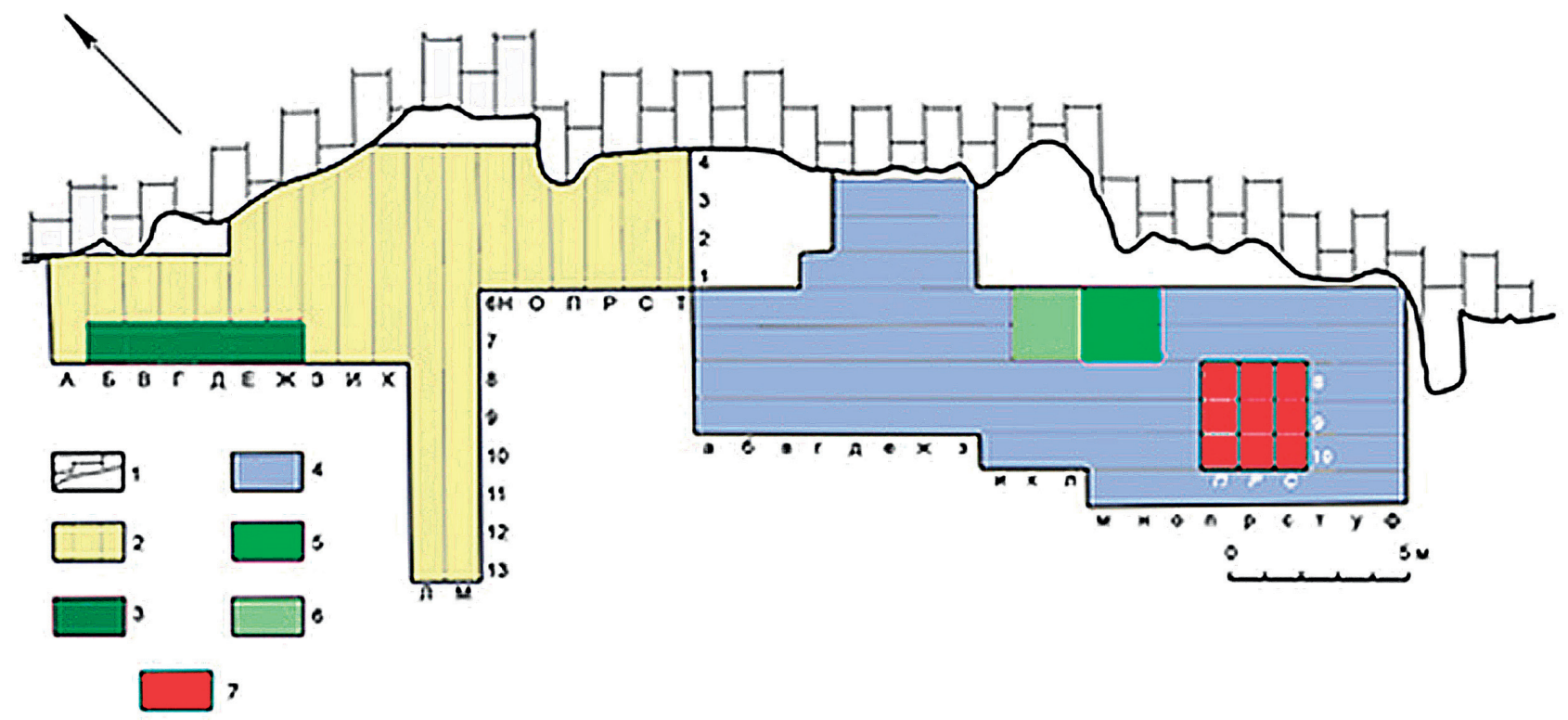

Fig. 4. Chokhskoye settlement. Summary of the excavation plan.

Symbols: 1 - rock; 2 - V. G. Kotovich's excavation 1955-1957 (excavation No. 1); 3 - a section of the lower layer excavated in 1974 by H. A. Amirkhanov; 4 - H. A. Amirkhanov's excavation 1980-1982.

(excavation No. 2); 5 - pit in 1980 (excavated to the rock base); 6 - pit in 1982 (excavated to the rock base); 7 - excavation of H.A. Amirkhanov 2021

Рис. 4. Чохское поселение. Сводный план раскопов.

Условные обозначения: 1 - скала; 2 - раскоп В.Г. Котовича 1955-1957 (раскоп № 1); 3 - участок нижнего слоя, раскопанный в 1974 г. Х.А. Амирхановым; 4 - раскоп Х.А. Амирханова 1980-1982 гг. (раскоп № 2); 5 - шурф 1980 г. (раскопан до скального основания); 6 - шурф 1982 г. (раскопан до скального основания); 7 - раскоп Х.А.Амирханова 2021 г.

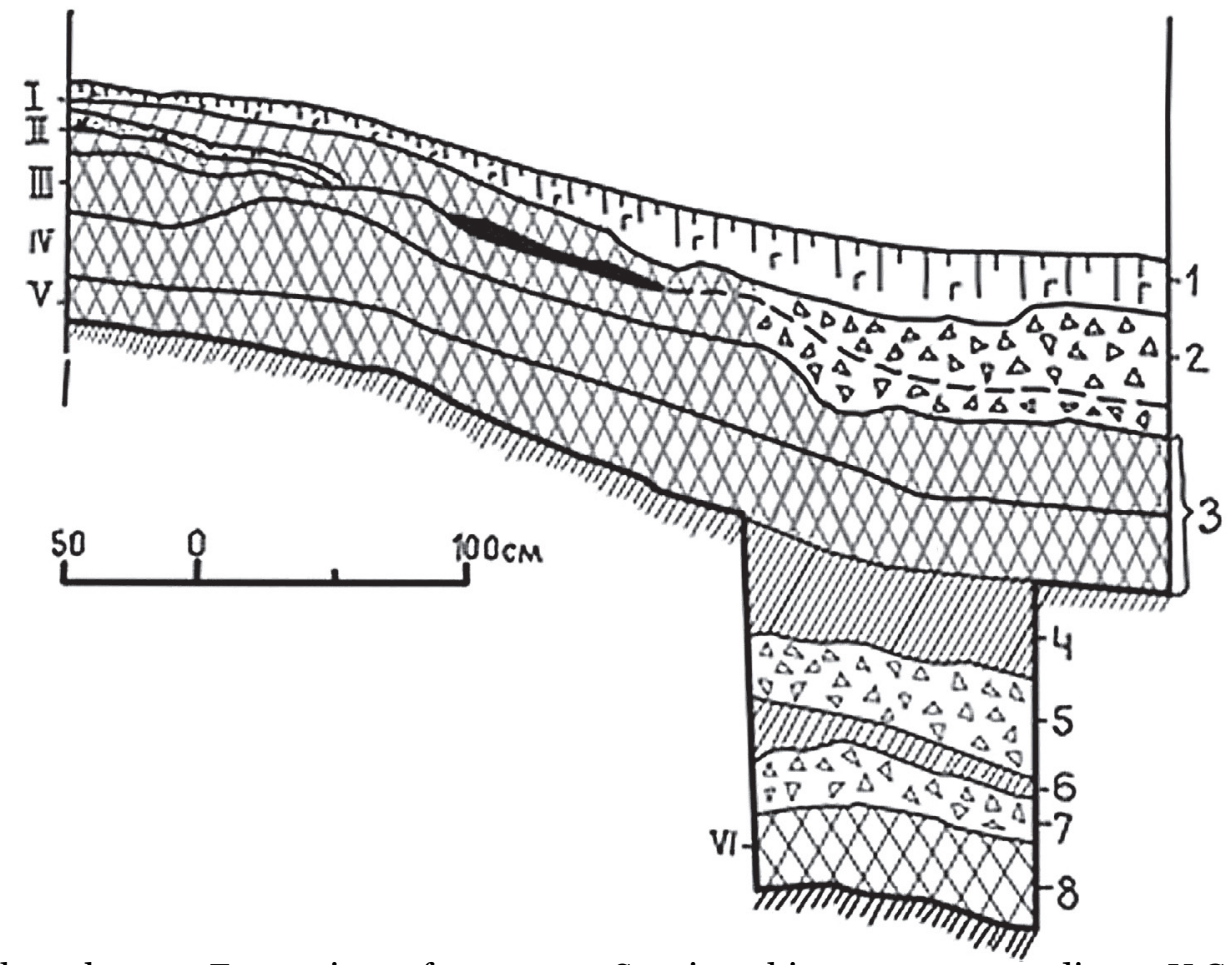

Fig. 5. Chokh settlement. Excavations of 1955-1957. Stratigraphic sequence according to V.G.Kotovich. Legend: on the left - cultural layers, on the right - geological layers

Рис. 5. Чохское поселение. Раскопки 1955-1957 гг. Разрез отложений по В. Г. Котовичу Цифровые обозначения: слева - культурные слои, справа - геологические слои 


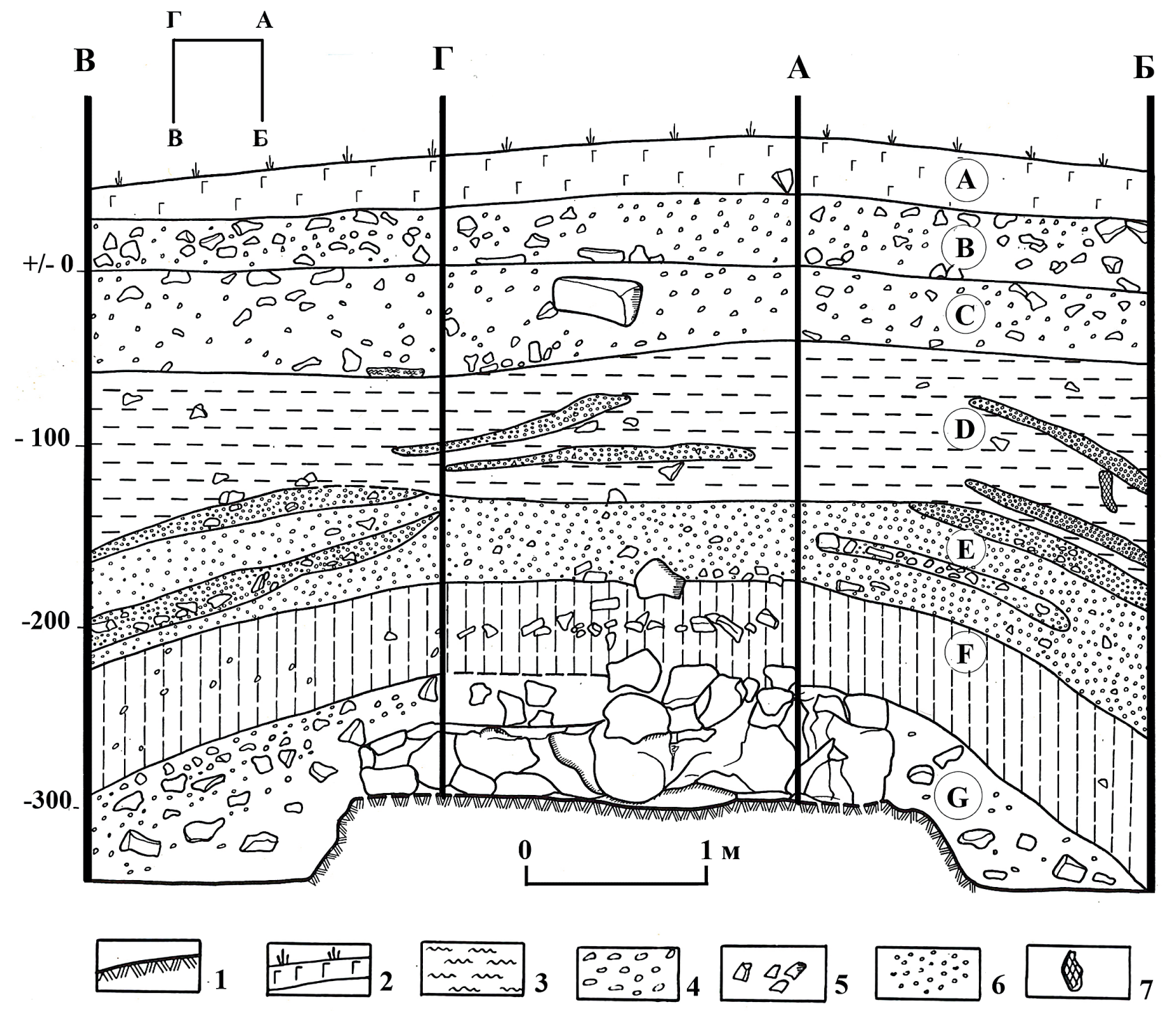

Fig. 6. Chokh settlement. The author's excavations in 1980. Full section of sediments (three-way scan of sections of the walls of the pit No. 1)

Symbols: 1 - rock; 2 - humus; 3 - hearth mass; 4 - crushed stone; 5 - blocks;

6 - crushed stone of the smallest fractions; 7 - wormholes

Рис. 6. Чохское поселение. Раскопки автора 1980 г. Полный разрез отложений (трёхсторонняя развертка разрезов стенок шурфа № 1)

Условные обозначения: 1 - скала; 2 - гумус; 3 - очажная масса; 4 - щебень; 5 глыбы; 6 - дресва; 7 - кротовины

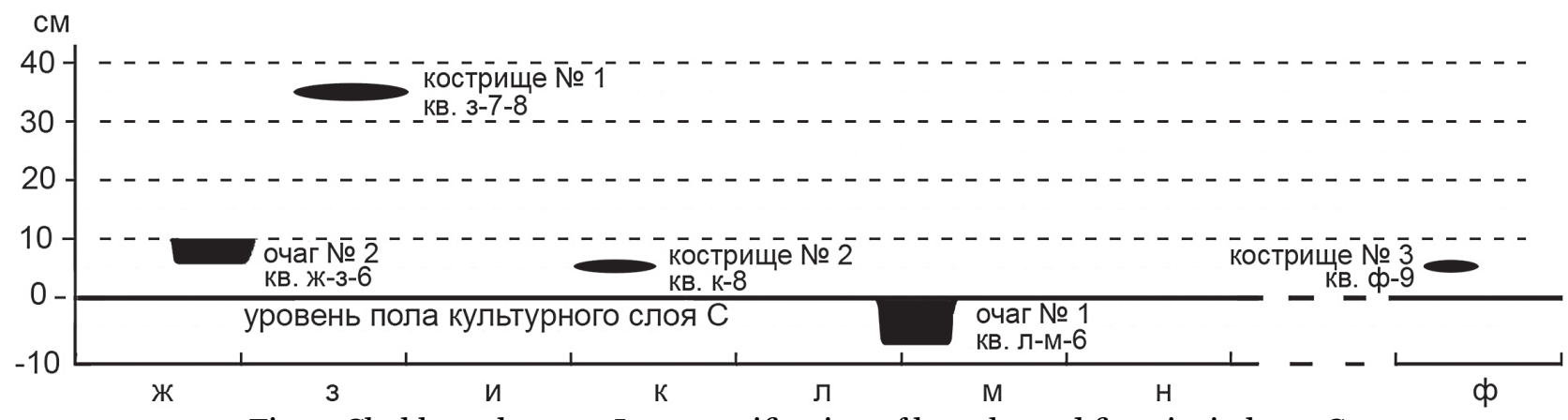

Fig. 7. Chokh settlement. Interstratification of hearths and fire pits in layer C

Рис. 7. Чохское поселение. Переслаивание очагов и кострищ в слое С 


\section{REFERENCES}

1. Amirkhanov HA. Chokh settlement. Man and his culture in the Mesolithic and Neolithic of the Mountainous Dagestan [Chokhskoye poselenie. Chelovek i yego kul'tura $v$ mezolite $i$ neolite Gornogo Dagestana]. Moscow, Nauka, 1987. (In Russ).

2. Kotovich VG. The Stone Age of Dagestan [Kamenniy vek Dagestana]. Makhachkala, 1967. (In Russ).

3. Formozov AA. Review of research on Mesolithic sites in the Caucasus [Obzor issledovaniy mezoliticheskikh stoyanok na Kavkaze]. Soviet archeology. 1963, 4:183-187. (In Russ).

4. Bader NO. Variants of the culture of the Caucasus at the end of Upper Paleolithic and Mesolithic [Varianty kul'tury Kavkaza kontsa verkhnego paleolita i mezolita]. Soviet archeology . 1965, 4:316. (In Russ).

5. Bader NO., Tsereteli LD. Mesolithic of the Caucasus [Mezolit Kavkaza] Archeology of the USSR. Mesolithic of the USSR. Moscow, 1989:93-105. (In Russ).

6. Nebieridze LD. Neolithic of the Western Transcaucasia [Neolit Zapadnogo Zakavkazya]. Tbilisi, 1972. (In Russ).

7. Gadzhiev MG. Early agriculture of the North-Eastern Caucasus: the Eneolithic and Early Bronze Age [Rannezemledel'cheskaya kul'tura Severo-Vostochnogo Kavkaza: epokha eneolita i ranney bronzy]. Moscow: Nauka, 1991. (In Russ).

8. Abramova GA. Palynological analysis of the Quaternary marine terraced complex of the Western Caspian region [Palinologicheskiy analiz chetvertichnogo morskogo terrasovogo kompleksa Zapadnogo Prikaspiya] Pollen analysis in geomorphological studies [Sporovo-pyl'tsevoy analiz pri geomorfologicheskikh issledovaniyakh]. Moscow, 1981: 96-106. (In Russ).

9. Maev EG. The Phases of the Mangyshlak regression of the Caspian Sea [Fazy mangyshlakskogo regressa Kaspiyskogo morya] Vestnik Moskovskogo universiteta. Seriya 5, Geografiya. 2009,1:15-20. (In Russ).

10. Gadzhiev MG. New data on the southern connections of Dagestan in the IV-III thousand years. BC [Novyye dannyye o yuzhnykh svyazyakh Dagestana v IV-III tys.l. do n.e.] KSIA. 1966, 108:55-61. (In Russ).

11. Chataigner Christine, Badalyan Ruben, Arimura Makoto. The Neolithic of the Caucasus. Oxford University Press, 2018:1-34.

\section{СПИСОК ЛИТЕРАТУРЫ}

1. Амирханов X.A. Чохское поселение. Человек и его культура в мезолите и неолите горного Дагестана. М.: Наука. 1987. 225 с.

2. Котович В.Г. Каменный век Дагестана. Махачкала, 1964. 225 с.

3. Формозов А.А. Обзор исследований мезолитических стоянок на Кавказе // Советская археология. 1963. № 4. С. 183 - 187.

4. Бадер Н.О. Варианты культуры Кавказа конца верхнего палеолита и мезолита // Coветская археология. 1965. № 4. С. 3 - 16.

5. Бадер Н.О., Церетели Л.Д. Мезолит Кавказа // Археология СССР. Мезолит СССР. М.: Наука, 1989. С. $93-105$.

6. Небиеридзе Л.Д. Неолит Западного Закавказья. Тбилиси, 1972.

7. Гаджиев М.Г. Раннеземледельческая культура Северо-Восточного Кавказа: эпоха энеолита и ранней бронзы. М.: Наука, 1991. 263 c.

8. Абрамова Г.А. Палинологический анализ четвертичного морского террасового комплекса Западного Прикаспия // Спорово-пыльцевой анализ при геоморфологических исследованиях. М.: Изд-во МГУ, 1981. С. $96-106$.

9. Маев Е.Г. Фазы мангышлакской регрессии Каспийского моря // Вестник Московского университета. Сер. 5. География. 2009. № 1. C.15- 20.

10. Гаджиев М.Г. Новые данные о южных связях Дагестана в IV-III тысячелетиях до н.э. // КСИА. 1966. Вып. 108. С. 55 - 61.

11. Chataigner Christine, Badalyan Ruben, Arimura Makoto. The Neolithic of the Caucasus Oxford University Press, 2018. P. 1-34.

The article was uploaded on September 4, 2021. The article was accepted for publication on October 2, 2021. 